\title{
Evlilikte Suçu Affetme ve Evlilik Uyumu İlişkisi*
}

\section{Relationship Between Marital Offense-Specific Forgiveness and Marital Adjustment}

\author{
Tayyibe Yaman Akpınar ${ }^{\text {a,** }}$, Özlem Altunsu Sönmez ${ }^{\text {b }}$ \\ ${ }^{\text {a } U z m . ~ P s i k o l o j i k ~ D a n ı s ̧ m a n ~ v e ~ A i l e ~ D a n ı s ̧ m a n ı, ~ M a m a k ~ R e h b e r l i k ~ v e ~ A r a s ̧ t ı r m a ~ M e r k e z i, ~ 06350, ~ A n k a r a / T u ̈ r k i y e . ~}$ \\ ORCID: 0000-0003-2980-1963

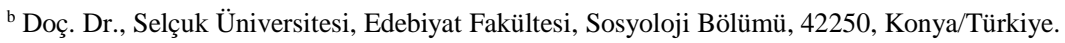 \\ ORCID: 0000-0002-6553-5351
}

\begin{tabular}{l} 
MAKALE BİLGİSİ \\
\hline Makale Geçmişi: \\
Başvuru tarihi: 24 Temmuz 2020 \\
Düzeltme tarihi: 01 Mart 2021 \\
Kabul tarihi: 06 Mart 2021 \\
\hline Anahtar Kelimeler: \\
Evlilik \\
Aile \\
Suçu Affetme \\
Evlilik Uyumu
\end{tabular}

\section{A R T I C L E IN F O}

Article history:

Received 24 July 2020

Received in revised form 01 March 2021

Accepted March 06 March 2021

Keywords:
Marriage
Family
Marital Offense-Specific Forgiveness
Marital Adjustment

ÖZ

$\mathrm{Bu}$ araştırma, evli bireylerin suçu affetme düzeyleri ve evlilik uyumu arasındaki ilişkileri belirlemeyi amaçlayan ilişkisel tarama modeli ile gerçekleștirilmiş nicel bir araștırmadır. Araştırmanın örneklemini 125 'i kadın ve 85 'i erkek 210 evli birey oluşturmuştur. Araştırma kapsamında, Evlilik uyumu Locke ve Wallace (1959) tarafından geliștirilmiș Evlilik Uyumu Ölçeği (EUÖ) ile Suçu Affetme ise Palegari, Regalia ve Fincham (2000) tarafından geliştirilmiş Evlilikte Suçu Affetme ölçeği (ESAÖ) ile ölçülmüştür. Araştırmanın sonuçlarına göre EUÖ anlaşma boyutu ile ESAÖ dargınlık-kaçınma boyutu arasında negatif yönlü yüksek düzeyde bir ilişkinin olduğu saptanmıştır. Ayrıca, EUÖ ilişki tarzı boyutu ile ESAÖ dargınlık-kaçınma boyutu arasında negatif yönlü orta düzeyde bir ilişkinin olduğu tespit edilmiştir. Son olarak, araştırmadan elde edilen bulgular literatür eşliğinde tartışılmış ve ortaya çıkan sonuçlar doğrultusunda öneriler getirilmiştir.

\section{A B S T R A C T}

This study is a quantitative research conducted with correlational survey model and aiming to determine the relationships between marital adjustment and marital offense-specific forgiveness level of married individuals. The sample of the study consisted of 210 married individuals including of 125 women and 85 men. While marital adjustment was measured in order to measure the quality of marriage by the Marital Adjustment Test (MAT) developed by Locke and Wallace (1959), marital offense-specific forgiveness was measured with the Marital Offense-Specific Forgiveness Scale (MOFS) developed by Palegari, Regalia and Fincham (2000). Finally, the findings of the research was discussed in the light of the literature and recommendations were made according to the results.

\section{Giriş}

Aile, sevgi ve nefret duygularını güçlü yaşadığımız ve beraberinde en derin doyumlarımızı ve acı veren hayal kırıklıklarımızı da yaşadığımız yerdir. Bir ailenin içinde dünyaya gelir ve yetişkinlikte evlilik yoluyla da yeni bir aile kurarız. Evlilik resmi, duygusal, davranısssal ve biyolojik yönleri olan sosyal bir sistem olarak karşımıza çıkar (Kışlak, 1999: 50). Eşlerin ve çevrenin beklentisi ise bu evliliğin başarılı olarak bir ömür boyu sürmesidir. Başarılı evliliklerde eşler kendilerini huzurlu, mutlu ve güven içinde

*Bu çalışma birinci yazarın 2019 yılında Doç. Dr. Özlem Altunsu Sönmez danışmanlığında Selçuk Üniversitesi Üniversitesi Sosyal Bilimler Enstitüsü Aile Danışmanlığı ve Eğitimi Anabilim Dalı'nda yürüttüğü "Bağlanma Stilleri ve Affetme Düzeyinin Evlilik Uyumuna Etkisi" başlıklı yüksek lisans tezinden türetilmiştir.

** Sorumlu yazar/Corresponding author

e-posta: tayyibeyaman@hotmail.com 
hissederler. Fakat bir birlikteliğin yürütülmesi zaman zaman zor ve sancılı olabilmektedir. Eğer eşler evlilik öncesindeki hayatlarını özlüyorsa veya evlendikleri için pişman olduklarını sıkça dile getiriyorlarsa bu evliliğin başarılı olduğu düşünülemez. Eşlerin evlilikten beklentilerinin gerçekleşmesi ancak eşler arasındaki sağlıklı ilişkinin sonucunda mümkün olabilir. Mutlu aileler, geleceğin sağlıklı ve güçlü toplumlarını oluşturacaktır. Bu bağlamda mutlu aile demek aynı zamanda mutlu toplum demektir. Mutlu ailelerde eşler sorumluluk sahibi, fedakâr, sadakatli, iradeli, duygu ve düşünce de hür ve inançlı bireyler olarak karşımıza çıkarlar. Başarılı bir evlilik, eşler arasında uyumun sağlanabildiği ölçüde elde edilebilir (Tarhan, 2010). Evlilik kadın erkek iki kişi arasında gerçekleşse de aile kurmak ve bunu sağlıklı bir biçimde oluşturmak ve devam ettirmek o aile içinde yetişecek çocuklar ve toplum ve onun geleceği açısından da önem teşkil etmektedir. Bu nedenle başlangıçta evlilikte uyum yakalamak önemli bir konu olarak karşımıza çıkar.

Spanier (1976), evlilik uyumunu eşlerin süreç içerisinde birbirlerine ve değişen koşullara uyum sağlaması olarak tanımlamış ve evlilik uyumunun, eşler arasındaki doyum, bağlılık, fikir birliği ve sevgi unsurlarının bir araya gelmesiyle oluştuğunu belirtmiştir (Akt., Kızılöz Başsayın, 2018: 5-6). Collins ve Coltrane'e (1991) göre ise evlilik uyumu; olumlu iletişim, evlilikten duyulan mutluluk, cinsel doyum ve eğer yeniden evlenilecek olunsa yine aynı kişi ile evlenme isteğidir (Akt., Yalçın, 2014: 251).

Evlilik uyumu "bir evliliğin zorunlu ve gönüllü niteliklerinin bir dengeye ulaşması" (Kışlak, 1999: 51) iken aileyi ilgilendiren konularda ortak bir karara varabilen, etkileşim halinde olan ve sorunlarını olumlu bir şekilde çözebilen çiftlerin evliliği de uyumlu bir evlilik olarak tanımlanır. Bu uyumlu birliktelik sonucunda evlilikten duyulan memnuniyet ve mutlulukta yüksek olacaktır (Erberk, Beştepe, Akar, Eradamlar ve Alpkan, 2005: 39). Ayrıca; evlilik uyumu hem aile içinde hem de aile dışındaki ilişkiler için belirleyici olduğundan oldukça önemlidir (Fışıloğlu 1992: 16). Bunların yanı sıra evlilik ilişkisi doğası gereği, bireylerin incinmesine neden olabilecek dinamiklere de sahiptir. İncinme sonucunda bireyler öfke, kızgınlık, üzüntü gibi duygular hissedebilmektedir. Ancak bütün evliliklerde görülebilecek incinme sonucunda birçok kişinin ilişkisine kaldığı yerden devam ettiği görülmektedir (Tayşi, 2007: 1). Bireylerin evlilikten duydukları mutluluk, uyum ve devamlılık için, bu olumsuz yaşantıların nasıl ele alındığ anlamak da çok önemlidir (Göztepe Gümüş, 2015: 42).

$\mathrm{Bu}$ noktada ise karşımıza; yaşanan bu olumsuzluklarda, bireylerin incindikleri, duygusal ya da fiziksel olarak örselendikleri durumlarla sonrasında nasıl bahşettiklerini anlamak ya da affetmenin rahatlığına kavuşup kavuşamadıklarını anlamak adına affetme kavramı çıkar.

Affetme, psikoloji, felsefe ve din gibi farklı disiplinlere konu olan geniş bir kavramdır (Ayten, 2009: 111). Alan yazın incelendiğinde araştırmacıların farklı affetme tanımlarına yer verdiği de görülmektedir. Fitzgibbons, Enright ve O’Brien (2004: 24), affetmeyi "başkalarının haksız muamelesine, entelektüel ve ahlaki bir tepki" olarak tanımlamaktadır. Affetme sürecinin ilk aşaması, hata yapan kişiyi anlamak ve ona karşı hissedilen kırgınlıktan vazgeçmektir. Bir süre sonra bu durum anlayış, duyarlılık, yardımseverlik ve hatta sevgi sunmaya kadar bile uzanabilir.
Bell (2008) affetme kavramını, gücenme ve saygısızlı̆̆ın üstesinden gelme olarak tanımlarken; Auerbach (2005: 475), affetme kavramını kızgınlığın bağışlanması ve öfke, nefret duygularının giderilmesi olarak tanımlamaktadır.

Alan yazındaki affetme tanımlarının çoğunluğu bireyin intikam alma gibi negatif duygularının empati, şefkat gibi pozitif duygularla yer değiştirmesini vurgulamaktadır (Aydın, 2017). Gordon ve Baucom (1998, 1999), affetmenin ilişkilerde iyileşme için kilit bir unsur olduğunu belirtmektedir ve affetmenin gerçekleşmesi için 3 bileşen ortaya koymaktadır. Bunlar ilişkiye resmin bütününü gören gerçekçi ve dengeli bir bakış açısı; partnere yönelik olumsuz düşünce ve cezalandırma isteğinin azalması; ilişkiye ve partnere yönelik inançların yeniden düzenlenmesi veya yapılandırılmasını içerir. Çolak, Koç, Eker ve Düşünceli'de (2017: 70), "sosyal yaşam için gerekli olan güven, sayg1, iş birliği, paylaşma, sorumluluk ve iletişim gibi dinamiklerin oluşmasında affedebilme davranışı son derece önemli" olduğunu vurgulamaktadır. Bireylerin affedici tutum sergilemelerinin yanında doğru affetme tercihleri yapmalarının da önemli olduğunu ifade etmektedirler. Bireyin neyi ne zaman affedeceği de önemlidir.

$\mathrm{Bu}$ araştırmada evli bireylerin suçu affetme düzeyleri ve evlilik uyumu ilişkisini araştırmak amaçlanmıştır.

\section{Yöntem ve Uygulama}

Araştırma, evli bireylerin suçu affetme ve evlilik uyumu ilişkisini belirlemeyi amaçlayan ilişkisel tarama çalışmasıdır. Tarama modelleri, "geçmişte ya da halen var olan bir durumu var olduğu şekliyle betimlemeyi amaçlayan araştırma yaklaşımlarıdır" (Karasar, 2015: 77). Araştırmanın çalışma grubunu $125^{\prime}$ i kadın 85 'i erkek toplam 210 evli birey oluşturmaktadır.

Araştırmada verileri "Kişisel Bilgi Formu”, "Evlilikte Uyum Ölçeği" ve "Evlilikte Suçu Affetme Ölçeği”" kullanılarak toplanmıştır. Evlilikte Uyum Ölçeği, Locke ve Wallace (1959) tarafından evliliğin niteliğini ölçmek amacıyla geliştirilmiş ve Türkçe çevirisi Kışlak (1999) tarafindan gerçekleştirilmiştir. 15 maddeden ve ilişki tarzı ve anlaşma şeklinde 2 alt boyuttan oluşan ölçeğinin iç tutarlık katsayısı .90’dır. Evlilikte Suçu Affetme Ölçeği ise Palegari, Regalia ve Fincham (2000) tarafindan geliştirilmiş ve Türkçe çevirisi Akın, Çolak ve Eroğlu (2012) tarafından gerçekleştirilmiştir. 10 madde ve 2 alt boyuttan oluşan ölçeğin dargınlıkkaçınma alt boyutunda iç tutarlık katsayısı. 79 ve .80, bağışlama alt boyutunda iç tutarlık katsayısı .80 ve .76 'dır.

Verileri toplamak amacıyla bir araya getirilen "Kişisel Bilgi Formu", "Evlilikte Suçu Affetme Ölçeği" ve "Evlilikte Uyum Ölçeği”" internet üzerinden yayınlanmış ve evli bireylere araştırma uygulanmıştır. Tüm istatistiksel analizler SPSS 24. paket programı ile yapılmıştır. Analizlerde tanımlayıcı istatistikler frekans (n), yüzde (\%), ortalama, standart sapma, minimum ve maksimum değerler olarak belirtilmiştir. İki grubun karşılaştırmalarında Student's t test, üç ve üzeri grupların karşılaştırmalarında One-way ANOVA test ve farklılığa neden olan grubun tespitinde Bonferroni testi kullanılmıştır. Korelasyon analizlerinde sayısal verilerin karşılaştırılmasında Pearson Product-Moment Korelasyon testi ile incelenmiştir. İstatistiksel anlamlılık $\mathrm{p}<0.01$ düzeyinde değerlendirilmiştir. 
Tablo 1. Evlilikte Uyum Ölçeği (EUÖ) ve Evlilikte Suçu Affetme Ölçeği (ESAÖ) iç tutarlılık analizi değerleri

\begin{tabular}{lcl}
\hline Ölçekler ve Alt Boyutları & Cronbach's Alpha & $\mathrm{N}$ \\
\hline Evlilikte Uyum Ölçeği (EUÖ) & .915 & 15 \\
Anlaşma & .908 & 9 \\
İlişki Tarzı & .760 & 6 \\
Dargınlık-Kaçınma & .833 & 6 \\
Bağışlama & .616 & 4 \\
\hline
\end{tabular}

\section{Bulgular}

Bu bölümde, araştırmanın amacına ve ana problemine uygun olarak toplanan verilerin istatistiksel çözümlemeleri sonucu elde edilen bulgular sunulmuştur.

1. Evli bireylerin evlilik uyumu demografik değişkenlere göre anlamlı düzeyde farklılaşmakta mıdır?

Evli bireylerin anlaşma boyutunun cinsiyet, eğitim düzeyi, yaş, ailede çalışan birey sayısı, çalışılan sektör, gelir düzeyi, evlenme şekli, çocuk sayısı, değişkenlerine göre farklılaşmadığ 1 görülürken; evlilik süresi ve eşle olan yaş farkına göre anlamlı düzeyde farklılaştığı saptanmıştır.

Tablo 2. Evli bireylerin EUÖ anlaşma toplam puan değerlerinin demografik değişkenlere göre dağılımı

\begin{tabular}{|c|c|c|c|c|c|c|}
\hline & \multirow[b]{2}{*}{$\mathrm{N}$} & & \multicolumn{4}{|c|}{ EUÖ Anlaşma Değerleri } \\
\hline & & & Ortalama & $\begin{array}{l}\text { Standart } \\
\text { Sapma }\end{array}$ & Min & Max \\
\hline & $0-2$ y1l & 52 & 35.73 & 5.111 & 15 & 44 \\
\hline & $3-6$ y1l & 47 & 32.23 & 8.183 & 10 & 45 \\
\hline $\begin{array}{l}\text { Eşle } \\
\text { Evlilik }\end{array}$ & $7-10$ yil & 34 & 29.68 & 11.064 & 0 & 44 \\
\hline Süresi & $11-15 \mathrm{y} 1 \mathrm{l}$ & 41 & 30.83 & 8.863 & 5 & 46 \\
\hline & $16-20$ y1l & 13 & 33.92 & 7.308 & 18 & 44 \\
\hline & $\begin{array}{l}21 \text { yll ve } \\
\text { üzeri }\end{array}$ & 23 & 29.48 & 8.774 & 13 & 44 \\
\hline Eşle & $0-3$ & 140 & 32.61 & 7.845 & 5 & 44 \\
\hline $\begin{array}{l}\text { Olan } \\
\text { Yaş }\end{array}$ & $4-7$ & 55 & 32.65 & 8.731 & 0 & 46 \\
\hline Fark1 & 8 ve üzeri & 15 & 26.93 & 11.823 & 3 & 41 \\
\hline
\end{tabular}

Evli bireylerin evlilik süreleri ile EUÖ anlaşma alt boyutu toplam puanlarının farklılaştığı ve bu durumun da istatistiksel olarak anlamlı olduğu $(F(5)=3.371, \mathrm{p}=0.006)$ saptanmıştır. Diğer bir ifade ile bireylerin evlilik süreleri, evlilikteki uyumlarında anlaşma düzeylerini etkilemektedir. 0-2 yıldır evli olan bireylerin evlilikteki uyumlarında anlaşma düzeylerinin 7-10 yıldır evli olan ve 21 ve üzeri yıldır evli olan bireylerin evlilikteki uyumlarında anlaşma düzeyinden daha fazla olduğu görülmektedir.

Evli bireylerin eşle olan yaş farkı durumu ile EUÖ anlaşma alt boyutu ortalama puanlarının farklılaştığı ve bu durumun da istatistiksel olarak anlamlı olduğu $(F(2)=3.188, \mathrm{p}=0.043)$ saptanmıştır. Diğer bir ifade ile evli bireylerin eşle olan yaş farkı, evli bireylerin evlilikteki uyumlarında anlaşma düzeylerini etkilemektedir. 8 ve üzeri yaş farkı olan bireylerin evlilikteki uyumlarında anlaşma düzeyinin, 0-3 yıl arasında yaş farkı olan ve 4-7 yıl yaş fark1 olan bireylerin evlilikteki uyumlarında anlaşma düzeyinden daha düşük olduğu görülmektedir.
Evli bireylerin ilişki tarzı boyutunun cinsiyet, eğitim düzeyi, ailede çalışan birey sayısı, gelir düzeyi, evlenme şekli, eşle olan yaş farkı değişkenlerine göre farklılaşmadığı görülürken yaş, çalışılan sektör, evlilik süresi ve çocuk sayısına göre anlamlı düzeyde farklılaştığı saptanmıştır.

Tablo 3. Evli bireylerin EUÖ ilişki tarzı toplam puanları değerlerinin demografik değişkenlere göre dağılımı

\begin{tabular}{|c|c|c|c|c|c|c|}
\hline & \multirow[b]{2}{*}{$\mathrm{N}$} & \multicolumn{4}{|c|}{ EUÖ İlişki Tarzı Değerleri } \\
\hline & & & Ortalama & $\begin{array}{l}\text { Standart } \\
\text { Sapma }\end{array}$ & Min & Max \\
\hline \multirow{4}{*}{$\begin{array}{l}\text { Yaş } \\
\text { Durumu }\end{array}$} & 20-29 yaş & 70 & 9.20 & 2.45 & 1 & 12 \\
\hline & 30-39 yaş & 80 & 7.93 & 3.10 & 0 & 12 \\
\hline & $40-49$ yaş & 41 & 7.71 & 3.10 & 1 & 12 \\
\hline & $\begin{array}{l}50 \text { yaş ve } \\
\text { üzeri }\end{array}$ & 19 & 6.21 & 2.99 & 1 & 12 \\
\hline \multirow{3}{*}{$\begin{array}{l}\text { Çalışılan } \\
\text { Sektör } \\
\text { Durumu }\end{array}$} & Çalışmıyorum & 22 & 6.91 & 3.66 & 1 & 12 \\
\hline & Kamu & 132 & 8.80 & 2.68 & 1 & 12 \\
\hline & Özel & 56 & 7.11 & 3.03 & 0 & 12 \\
\hline \multirow{6}{*}{$\begin{array}{l}\text { Eşle Evlil } \\
\text { Süresi } \\
\text { Durumu }\end{array}$} & $0-2$ y1l & 52 & 9.54 & 2.191 & 2 & 12 \\
\hline & $3-6$ y1l & 47 & 8.79 & 2.579 & 3 & 12 \\
\hline & k7-10 y1l & 34 & 7.41 & 3.105 & 0 & 12 \\
\hline & $11-15 \mathrm{y} 1 \mathrm{l}$ & 41 & 7.44 & 3.362 & 1 & 12 \\
\hline & $16-20 \mathrm{y} 1 \mathrm{l}$ & 13 & 8.08 & 2.985 & 2 & 12 \\
\hline & $\begin{array}{l}21 \text { yll ve } \\
\text { üzeri }\end{array}$ & 23 & 6.13 & 3.020 & 1 & 12 \\
\hline \multirow{3}{*}{$\begin{array}{l}\text { Çocuk } \\
\text { Sayıs1 }\end{array}$} & 0 & 57 & 9.00 & 2.535 & 0 & 12 \\
\hline & $1-2$ & 136 & 7.85 & 3.123 & 1 & 12 \\
\hline & $3-4$ & 17 & 7.71 & 3.037 & 2 & 12 \\
\hline
\end{tabular}

Evli bireylerin yaş değişkeni ile EUÖ ilişki tarzı alt boyutu toplam puanlarının farklılaştığ 1 ve bu durumun da istatistiksel olarak anlamlı olduğu $(F(3)=6.415, \mathrm{p}<0.001)$ saptanmıştır. Diğer bir ifade ile evli bireylerin yaş aralığı, evli bireylerin evlilikteki uyumlarında ilişki tarzı düzeyini etkilemektedir. 20-29 yaş aralığında olan evli bireylerin evlilikteki uyumlarında ilişki tarzı düzeyinin, 30-39 yaş aralığında olan ve 50 yaş ve üzeri yaş aralığında olan evli bireylerin evlilikteki uyumlarında ilişki tarzı düzeyinden, daha fazla olduğu görülmektedir.

Evli bireylerin çalıştıkları sektör ile EUÖ ilişki tarzı alt boyutu toplam puanlarının farklılaştığı ve bu durumun da istatistiksel olarak anlamlı olduğu $(F(2)=9.038, \mathrm{p}<0.001)$ saptanmıştır. Diğer bir ifade ile evli bireylerin çalıştıkları sektör, evli bireylerin evlilikteki uyumlarında ilişki tarzı düzeyini etkilemektedir. Kamu sektöründe çalışan evli bireylerin evlilikteki uyumlarında ilişki tarzı düzeyinin, çalışmayan (evli-ev hanımı-öğrenci) ve özel sektörde çalışan evli bireylerin evlilikteki uyumlarında ilişki tarzı düzeyinden, daha fazla olduğu saptanmıştır.

Evli bireylerin evlilik süreleri ile EUÖ ilişki tarzı alt boyutu ortalama puanlarının farklılaştığı ve bu durumun da istatistiksel olarak anlamlı olduğu $(F(5)=6.325, \mathrm{p}<0.001)$ saptanmıştır. Diğer bir ifade ile evli bireylerin evlilik süreleri, evli bireylerin evlilikteki uyumlarında ilişki tarzı 
düzeylerini etkilemektedir. 0-2 y1ldır evli olan bireylerin evlilikteki uyumlarında ilişki tarzı düzeyinin, 7-10 yıldır evli olan, 11-15 yıldır evli olan ve 21 ve üzeri yıldır evli olan bireylerin evlilikteki uyumlarında ilişki tarzı düzeyinden daha fazla olduğu görülmektedir. 3-6 yıldır evli olan bireylerin evlilikteki uyumlarında ilişki tarzı düzeyinin, 21 ve üzeri yıldır evli olan bireylerin evlilikteki uyumlarında ilişki tarzı düzeyinin daha fazla olduğu görülmektedir.

Evli bireylerin çocuk sayısı değişkeni ile EUÖ ilişki tarzı alt boyutu toplam puanlarının farklılaştığı ve bu durumun da istatistiksel olarak anlamlı olduğu $(F(2)=3.207, \mathrm{p}=0.042)$ saptanmıştır. Diğer bir ifade ile evli bireylerin çocuk sayısı, evli bireylerin evlilikteki uyumlarında ilişki tarzı düzeyini etkilemektedir. Çocuğu olmayan olan evli bireylerin evlilikteki uyumlarında ilişski tarzı düzeyinin, 1-2 çocuğu olan evli bireylerin evlilikteki uyumlarında ilişki tarzı düzeyinden, daha fazla olduğu görülmektedir.

2. Evli bireylerin affetme düzeyleri demografik değisskenlere göre anlaml düzeyde farklllaşmakta mıdır?

Evli bireylerin dargınlık-kaçınma boyutunun cinsiyet, eğitim düzeyi, yaş, ailede çalışan birey sayısı, çalışılan sektör, gelir düzeyi, evlilik süresi, evlenme şekli, eşle olan yaş fark1, çocuk sayısı, değişkenine farklılaşmadığı saptanmıştır.

Evli bireylerin bağışlama boyutunun cinsiyet, eğitim düzeyi, ailede çalışan birey sayısı, çalışılan sektör, gelir düzeyi, evlilik süresi, evlenme şekli, eşle olan yaş farkı ve çocuk sayısına göre farklılaşmadığı görülürken; yaşa göre anlamlı düzeyde farklılaştığı saptanmıştır.

Tablo 4. Evli bireylerin ESAÖ bağışlama toplam puan değerlerinin demografik değişkenlere göre dağglımı

\section{ESAÖ Bağışlama Değerleri}

\begin{tabular}{|c|c|c|c|c|c|c|}
\hline & \multirow{2}{*}{$\mathrm{N}$} & & & & & \\
\hline & & & Ortalama & $\begin{array}{l}\text { Standart } \\
\text { Sapma }\end{array}$ & Min & $\operatorname{Max}$ \\
\hline \multirow{4}{*}{$\begin{array}{l}\text { Yaş } \\
\text { Durumu }\end{array}$} & $20-29$ yaş & 70 & 3.54 & 1.07 & 1.00 & $\overline{12.00}$ \\
\hline & 30-39 yaş & 80 & 3.19 & 1.25 & .00 & 12.00 \\
\hline & $40-49$ yaş & 41 & 3.26 & 1.16 & 1.00 & 12.00 \\
\hline & $\begin{array}{l}50 \text { yaş ve } \\
\text { üzeri }\end{array}$ & 19 & 2.57 & 1.31 & 1.00 & 10.00 \\
\hline
\end{tabular}

Evli bireylerin yaş durumları ile ESAÖ bağışlama alt boyutu ortalama puanlarının farklılaştığı ve bu durumun da istatistiksel olarak anlamlı olduğu $(F(3)=3.569, \mathrm{p}=0.015)$ saptanmıştır. Diğer bir ifade ile evli bireylerin yaş aralığ 1 , evli bireylerin bağışlama boyutundaki affetme düzeylerini etkilemektedir. 20-29 yaş aralığında olan evli bireylerin bağışlama boyutu düzeylerinin, 50 yaş ve üzeri yaş aralığında olan evli bireylerin bağışlama boyutu affetme düzeylerinden, daha fazla olduğu görülmektedir.

3. Evli bireylerin suçu affetme düzeyleri ve evlilik иyuти arasında anlamlı düzeyde bir ilişki var mıdır?

Ankette kullanılan Evlilikte Uyum Ölçeğinin (EUÖ) ve Evlilikte Suçu Affetme Ölçeğinin katılımcılara uygulanması neticesinde elde edilen verilerin arasındaki ilişki Pearson Product-Moment Korelasyon testi ile incelenmiş olup istatistiksel anlamlılık $\mathrm{p}<0.01$ düzeyinde değerlendirilmiştir. Yapılan testler neticesinde;
EUÖ anlaşma toplam puanları ile EUÖ ilişki tarzı toplam puanları arasındaki ilişkiye bakıldığında, ikili arasında pozitif yönlü yüksek düzeyde bir ilişkinin olduğu, evli bireylerin evlilikteki anlaşma düzeyleri arttıkça, evli bireylerin ilişki tarzı düzeylerinin de arttığı, bu doğrusal ilişkinin de $\left(r_{s}(210)=0.715, p<0.001\right) \quad$ istatistiksel olarak anlamlı olduğu saptanmıştır.

EUÖ anlaşma boyutu toplam puanları ile ESAÖ dargınlıkkaçınma boyutu ortalama puanları arasındaki ilişkiye bakıldığında, ikili arasında negatif yönlü yüksek düzeyde bir ilişkinin olduğu, evli bireylerin evlilikteki anlaşma düzeyleri arttıkça, dargınlık-kaçınma düzeylerinin azaldığı, bu doğrusal ilişkinin de $\left(r_{s}(210)=-0.636, p<0.001\right)$ istatistiksel olarak anlamlı olduğu saptanmıştır.

EUÖ anlaşma boyutu toplam puanları ile ESAÖ bağışlama boyutu ortalama puanları arasındaki ilişkiye bakıldığında, ikili arasında bir ilişkinin olmadı $\breve{g} 1\left(r_{s}(210)=-0.134, p=\right.$ 0.053) saptanmıştır.

EUÖ ilişki tarzı boyutu toplam puanları ile ESAÖ dargınlıkkaçınma boyutu ortalama puanları arasındaki ilişkiye bakıldığında, ikili arasında negatif yönlü orta düzeyde bir ilişskinin olduğu, evli bireylerin evlilikteki iliş̧i tarzı düzeyleri arttıça, evli bireylerin dargınlık-kaçınma düzeylerinin azaldığı, bu doğrusal ilişkinin de $\left(r_{s}(210)=\right.$ $-0.475, p<0.001)$ istatistiksel olarak anlamlı olduğu saptanmıştır.

EUÖ ilişki tarzı boyutu toplam puanları ile ESAÖ bağışlama boyutu ortalama puanları arasındaki ilişkiye bakıldığında, ikili arasında bir ilişkinin olmadığ $1\left(r_{s}(210)=-0.005\right.$, $p=0.940$ ) saptanmıştır.

\section{Sonuç}

\section{Evli bireylerin demografik değişskenlere göre evlilik uyumunun incelenmesi}

Evli bireylerin anlaşma ve ilişki tarzı boyutunun kadın ve erkek katılımcılar lehine değişmediği görülmüştür. Elde edilen bu bulgular Kışlak ve Çabukça'nın (2002) araştırması ile benzer sonuçlar gösterirken Nalbant'ın (2017) araştırması ile benzer sonuçlar göstermemektedir. Nalbant'ın (2017) araştırmasında erkeklerin evlilik uyumunun kadınlara göre anlamlı düzeyde yüksek olduğu saptanmıştır.

Evli bireylerin eğitim düzeyine göre evlilik uyumları incelendiğinde katılımcılar arasında anlamlı bir farkın bulunmadığı görülmüştür. Elde edilen bu bulgular Kışlak ve Çabukça'nın (2002) ve Kublay'ın (2013) araştırması ile benzer sonuçlar göstermektedir.

Evli bireylerin yaşa göre anlaşma boyutu incelendiğinde katılımcılar arasında anlamlı bir farkın bulunmadığ görülmüştür. Elde edilen bu bulgular Demir'in (2016) araştırması ile benzer sonuçlar göstermektedir. Evli bireylerin yaşa göre ilişki tarzı incelendiğinde anlamlı düzeyde farklılaşmanın olduğu görülmüştür. Araştırma bulgularına göre 20-29 yaş aralığındaki evli bireylerin ilişki tarzı, 30-39 yaş ve 50 yaş ve üzeri aralığındaki evli bireylerin ilişki tarzından anlamlı düzeyde yüksektir. Bu bulgular Kışlak ve Çabukça'nın (2002) araştırması ile benzer sonuçlar göstermezken Kublay'ın (2013) araştırması ile benzer sonuçlar göstermektedir. Kublay'ın (2013) araştırmasına 
göre bireylerin yaşları arttıkça evlilik uyumlarının azaldığı sonucu elde edilmiştir.

Evli bireylerin ailede çalş̧an birey durumuna göre evlilik uyumları incelendiğinde katılımcılar arasında anlamlı bir farkın bulunmadığı saptanmıştır.

Evli bireylerin çalışılan sektöre göre anlaşma boyutu incelendiğinde katılımcılar arasında anlamlı bir farkın bulunmadığı görülmüştür. Evli bireylerin çalıştıkları sektöre göre ilişki tarzı incelendiğinde anlamlı düzeyde farklılaş̧manın olduğu görülmüştür. Araştırma bulgularına göre kamu sektöründe çalışan evli bireylerin ilişki tarzı, çalışmayan ve özel sektörde çalışan evli bireylerin iliş̧ki tarzından anlamlı düzeyde yüksektir. Bu bulgular Kublay'ın (2013) araştırması ile benzer sonuçlar göstermemektedir.

Evli bireylerin gelir düzeyine göre evlilik uyumları incelendiğinde katılımcılar arasında anlamlı bir farkın bulunmadığ 1 görülmüştür. Elde edilen bu bulgular Demir'in (2016) araştırması ile benzer sonuçlar göstermektedir.

Evli bireylerin evlilik süresine göre anlaşma boyutu incelendiğinde anlamlı düzeyde farklılaşmanın olduğu görülmüştür. Araştırma bulgularına göre evlilik süresi 0-2 yıl aralı̆̆ından olan bireylerin anlaşma boyutu, evlilik süresi 7 10 yıl ve 21 ve üzeri yıl aralığından olan bireylerin anlaşma boyutundan anlamlı düzeyde yüksektir. $\mathrm{Bu}$ bulguların Demir'in (2016) araştırması ile ortak noktaları bulunmaktadır. Demir'in (2016) çalışmasına göre evlilik süresi arttıkça evlilik uyumunun azaldığı saptanmıştır.

Bireylerin evlilik süresine göre ilişki tarzı incelendiğinde anlamlı düzeyde farklılaşmanın olduğu görülmüştür. Elde edilen araştırma bulgularına göre evlilik süresi $0-2$ yıl aralığından olan bireylerin ilişki tarzının, evlilik süresi 7 yıldan fazla olan bireylerin ilişki tarzından anlamlı düzeyde yüksektir. Araştırma bulgularına göre evlilik süresi 3-6 yıl aralığından olan bireylerin ilişki tarzının, evlilik süresi 21 yıldan fazla olan bireylerin ilişki tarzından anlamlı düzeyde yüksektir. Elde edilen bu bulgular Kışlak ve Çabukça'nın (2002) araştırması ile benzer sonuçlar göstermezken, Kublay'ın (2013) araştırması ile benzer noktaları bulunmaktadır. Kublay'ın (2013) araştırmasında 26-35 yıl aralığındaki evliliklerde, evlilik süresi arttıkça evlilik uyumunun düştüğü görülürken, 26-35 yıl sonrasında tekrar bir artışın olduğu sonucuna ulaşılmıştır. Ayrıca araştırmanın bir diğer sonucu ise $0-5$ yıl arasında evli olan bireylerinin evlilik uyumlarının 6-15 ve 16-25 yıl aralığında olan evliliklerden yüksek olduğudur. Kublay (2013) bu sonuçları evlilik süresi arttıkça aileye gelen yeni üyelerle birlikte maddi manevi sorumlulukların artması, evliliğin ilk yıllarına göre heyecanının azalması ile açıklamaktadır.

Bireylerin evlenme şekillerine göre evlilik uyumları incelendiğinde katılımcılar arasında anlamlı bir farkın bulunmadığ 1 görülmüştür. Elde edilen bu bulgular Kublay'ın (2013) araştırması ile benzer sonuçlar göstermektedir. Günümüzde evlenme biçimlerine bakıldığında görücü usulü evliliklerin geleneksel şekilde devam etmediği, bireylerin karşı tarafı tanımak adına kendilerine zaman verdikleri görülmekte ve bu durumun da evlilikler arasındaki farkı ortadan kaldırdığı görülmektedir.

Evli bireylerin eşle olan yaş farkına göre anlaşma boyutu incelendiğinde anlamlı düzeyde farklılaşmanın olduğu görülmüştür. Elde edilen araştırma bulgularına göre eşiyle 0-
7 yıl aralığında yaş farkı olan evli bireylerin anlaşma boyutu, eşiyle 8 ve üzeri yıl aralığında yaş farkı olan bireylerin anlaşma boyutundan anlamlı düzeyde yüksektir. Elde edilen bu bulguların Kublay'ın (2013) araştırması ile ortak özellikler gösterdiği görülmektedir. Kublay'ın (2013) araştırmasına göre eşle olan yaş farkı arttıkça evlilik uyumunun düștüğü yaş fark1 15 ve üzeri olan evliliklerde evlilik uyumunda tekrar bir artış olduğu görülmüsşür. Evli bireylerin eşle olan yaş farkına göre ilişki tarzı incelendiğinde katılımcılar arasında anlamlı bir farkın bulunmadığı görülmüştür.

Evli bireylerin çocuk sayısına göre anlaşma boyutu incelendiğinde katılımcılar arasında anlamlı bir farkın bulunmadığı görülmüştür. Evli bireylerin çocuk sayısına göre ilişki tarzı incelendiğinde anlamlı düzeyde farklılaşmanın olduğu görülmüştür. Araştırma bulgularına göre çocuğu olmayan evli bireylerin ilişki tarzı, 1-2 çocuğu olan bireylerin ilişki tarzından anlamlı düzeyde yüksektir. Alan yazındaki araştırmalar incelendiğinde Kışlak ve Çabukça'nın (2002) çalışmasında çocuk sayısının evlilik uyumunu etkilemediği görülürken, Kublay'ın (2013) araştırmasına göre sahip olunan çocuk sayısı 4 olan evlilikler dışında, çocuk sayısı arttıkça evlilik uyumunun düştüğü, 4 çocuğa sahip bireylerde ise evlilik uyumunun tekrar arttı̆̆ 1 görülmüştür.

\section{Evli bireylerin demografik değişkenlere göre evlilikte suçu affetme düzeylerinin incelenmesi}

Evli bireylerin cinsiyete göre affetme düzeyleri incelendiğinde kadın ve erkek bireyler arasında anlamlı bir farkın bulunmadığ görülmüştür. Bu bulgular Seyfi'nin (2017) ve Sivri'nin (2019) araştırması ile benzer sonuçlar göstermezken, Tayşi (2007), Ayten ve Tura'nın (2012), Kaya (2015) ve Besim'in (2017), araştırması ile benzer sonuçlar göstermektedir. Tayşi'nin (2007) araştırmasında affetme yönünden kadın ve erkekler arasında anlamlı düzeyde farklılaşma görülmezken, kadınların eşlerine daha çok kırıldıklarını dile getirdikleri görülmüştür.

Evli bireylerin eğitim düzeyine göre affetme düzeyleri incelendiğinde katılımcılar arasında anlamlı bir farkın bulunmadığı görülmüştür. Elde edilen bu bulgular Gürbüz'ün (2016) ve Güzel'in (2016), araştırması ile benzer sonuçlar göstermektedir.

Evli bireylerin yaşa göre dargınlık-kaçınma boyutu incelendiğinde katılımcılar arasında anlamlı bir farkın bulunmadığı saptanmıştır. Bu bulgular Güzel'in (2016), araştırması ile benzer sonuçlar göstermektedir. Evli bireylerin yaşa göre bağışlama düzeyi incelendiğinde anlamlı düzeyde farklılaşmanın olduğu görülmektedir. Araştırma bulgularına göre 20-29 yaş aralığındaki evli bireylerin bağışlama düzeyi, 50 yaş ve üzerindeki evli bireylerin bağışlama düzeyinden anlamlı düzeyde yüksektir. Elde edilen bu bulgular Ayten'in (2009), araştırması ile benzer sonuçlar göstermemektedir.

Evli bireylerin ailede çalışan birey durumuna, çalışılan sektöre, gelir düzeyine, evlenme şekline ve eşle olan yaş farkına göre affetme düzeyleri incelendiğinde katılımcılar arasında anlamlı bir farkın bulunmadığı görülmüş̧ür.

Evli bireylerin evlilik süresine göre affetme düzeyleri incelendiğinde katılımcılar arasında anlamlı bir farkın 
bulunmadığg görülmüştür. Elde edilen bu sonuçlar Fenell'in (1993) çalışması ile benzer sonuçlar göstermemektedir.

Evli bireylerin çocuk sayısına göre affetme düzeyleri incelendiğinde katılımcılar arasında anlamlı bir farkın bulunmadığ1 görülmüştür. Elde edilen bu bulgular Gürbüz'ün (2016), araştırması ile benzer sonuçlar göstermektedir.

\section{Evli bireylerin suçu affetme düzeyleri ve evlilik uyumları arasindaki ilişkinin incelenmesi}

EUÖ anlaşma boyutu ile EUÖ ilişki tarzı toplam puanları arasında pozitif yönlü yüksek düzeyde bir ilişkinin olduğu, evli bireylerin anlaşma düzeyleri arttıkça ilişki tarzı düzeylerinin de arttığı görülmüştür. Bunun anlamı evli bireylerin aile bütçesi, duyguların ifade edilmesi, arkadaşlık ilişkileri, cinsellik ve yaşam felsefesi gibi konulardaki anlaşma düzeyi arttıkça çiftlerin boş zamanlarını, ev dışı etkinlikleri, güven ilişkisi ve çatışma çözmeyi kapsayan ilişki tarzında da olumlu bir etkinin olduğudur.

EUÖ anlaşma boyutu ile ESAÖ dargınlık-kaçınma boyutu ortalama puanları arasında negatif yönlü yüksek düzeyde bir ilişkinin olduğu, evlilikte anlaşma düzeyi arttıkça dargınlıkkaçınma boyutunun azaldığı saptanmıştır. Eşler arasında anlaşma düzeyi arttıkça eşe duyulan kırgınlıkların ve eşten kaçınma durumunun azaldığı görülmüştür.

EUÖ anlaşma boyutu ile ESAÖ bağışlama boyutu ortalama puanları arasında anlamlı bir ilişkinin olmadığı görülmüştür. Elde edilen bu bulgular Tayşi’nin (2007) araştırması ile benzer sonuçlar göstermektedir. Tayşi'nin (2007) araştırmasında algılanan zararın şiddeti arttıkça affetmenin azaldığ 1 da vurgulanmıştır. Bu araştırma da göstermiştir ki eşler birbirlerini bağışlamasalar da kırgınlıklarla evliliklerine devam etmektedirler.

EUÖ ilişki tarzı boyutu ile ESAÖ dargınlık-kaçınma boyutu ortalama puanları arasında negatif yönlü orta düzeyde bir ilişkinin olduğu, evlilikte ilişki tarzı düzeyi arttıkça dargınlık-kaçınma boyutunun azaldığı saptanmıştır.

EUÖ ilişki tarzı boyutu ile ESAÖ bağışlama boyutu ortalama puanları arasında anlamlı bir ilişkinin olmadığı görülmüştür.

Araştırma verilerinden elde edilen sonuçlar doğrultusunda aşağıdaki önerilere yer verilmiştir:

(i) Suçu bağışlamanın yalnızca yaşa göre anlamlı düzeyde farklılaştığ 1 saptanmış ve çalışma grubunun suçu affetmediği fakat evliliklerine de devam ettikleri anlaşılmaktadır. $\mathrm{Bu}$ bağlamda alan uzmanlarına ESAÖ bağışlama boyutu ile EUÖ arasındaki ilişkide algılanan zararın şiddetinin aracı rolünün çalışılması önerilebilir. Ayrıca bu konuda farklı çalışma grupları ve/ veya farklı değişkenler ile yeni araştırmaların gerçekleştirilmesi, sonuçlar arası tutarlılığ görme ve araştırmacılara yön verme açısından büyük katkılar sağlayabilir.

(ii) Uygulamaya yönelik ise evlilik öncesi çiftlerin genellikle evliliğe ilişkin beklentilerinin olduğu fakat genellikle beklentilerin ve yaşantıların uyuşmadığ görülmektedir. Dolayısıyla evliliğin ilk yıllarında bireyler hayal kırıklıkları yaşayabilmektedir. $\mathrm{Bu}$ bağlamda evlilik öncesinde çiftler evlilik terapisine yönlendirilerek önleyici çalışmalar yapılabilir; bireylerin evlilikten beklentileri, evlilik ilişkisinin getirdiği sorumluluklar ve ilişkilerin kendine özgü yapısı hakkında danışmanlık hizmeti verilebilir. Aynı şekilde evli çiftler için ihtiyaç duyduklarında destek alabilecekleri aile danışmanlığı hizmetleri yaygınlaştırılabilir.

\section{Kaynakça}

Acar, A., Nemutlu, E., Gürhan, G., \& Liman, V. (2004). Hacettepe Üniversitesi Eczacılık Fakültesi Araştırma Görevlilerinin İş Memnuniyeti ve Bunu Etkileyen Faktörler. Hacettepe Üniversitesi Eczacılık Fakültesi Dergisi, 24(2), 95-106.

Akın, A., Çolak, T. S. ve Eroğlu, N. (17- 21 June 2012). Turkish version of the Marital Offence- Specific Forgiveness Scale (MOFS). Paper presented at the International Interdisciplinary Social Inquiry Conference- IISIC, Bursa, Turkey.

Auerbach, Y. (2005). Forgiveness and reconciliation: The religious dimension. Terrorism and Political Violence, 17, 469-485.

Aydın, F. T. (2017). Pozitif bir karakter gücü olarak affedicilik. The Journal of Happiness \& Well-Being, 5 (1), 1- 22.

Ayten, A. (2009). Affedicilik ve din affetme eğilimi ve dindarlıkla ilişkisi üzerine ampirik bir araştırma. Marmara Üniversitesi Ilahiyat Fakültesi Dergisi, 37, 111-128.

Ayten, A. ve Tura, H. (2017). Affetme ve dindarlık, hayat memnuniyetini nasil destekler? İslami İlimler Dergisi, 12 (3), 27- 54.

Bell, M. (2008). Forgiving someone for who they are (and not just they've done). Philosophy and Phenomenological Research, 77 (3), 625- 658.

Besim, G. (2017). Üniversite Öğrencilerinde Affetme, Bitirilmemiş İşler ve Öfke. Yüksek Lisans Tezi. Hacettepe Üniversitesi Eğitim Bilimleri Enstitüsü, Ankara.

Çolak, T. S., Koç, M., Eker, H. ve Düşünceli, B. (2017). Ortaöğretim öğrencilerinde affetme esnekliği ölçeği: Geçerlik ve güvenirlik çalışması. International Journal of Human Sciences, 14 (1), 63-73.

Demir, D. (2016). Evlilik Uyumu ile Bağlanma Stilleri ve Kişilerarası Problem Çözme Davranışı Arasındaki İlişkinin İncelenmesi. Yüksek Lisans Tezi. Maltepe Üniversitesi Sosyal Bilimler Enstitüsü, İstanbul.

Erberk, E., Beştepe, E., Akar, H., Eradamlar, N. ve Alpkan, R. L. (2005). Evlilik uyumu. Düşünen Adam, 18 (1), 39-47.

Fenell, D. L. (1993). Characteristics of long- term first marriages. Journal of Mental Health Counseling, 15 (4), 446- 460.

F1şıloğlu, H. (1992). Lisansüstü öğrencilerinin evlilik uyumu. Psikoloji Dergisi, 7 (28), 16- 23. 
Fitzgibbons, R., Enright, R. and O’Brien, T. (2004). Learning to forgive. American School Board Journaly, 191, 24- 26.

Gordon, K. C. and Baucom, D. H. (1998). Understanding betrayals in marriage: A synthesized model of forgiveness. Family Process, 37 (4), 425-449.

Gordon, K. C. and Baucom, D. H. (1999). A multitheoretical intervention for promoting recovery from extramarital affairs. Clinical Psychology: Science And Practice, 6 (4), 382-399.

Göztepe Gümüş, I. (2015). Evli Bireylerde Bağışlama, Tekrarlayıcı Düşünme Düzeyi İle Ruh Sağlığı ve Evlilik Uyumu Arasındaki İlişkiler. Yüksek Lisans Tezi. Ankara Üniversitesi Sosyal Bilimler Enstitüsü, Ankara.

Gürbüz, E. (2016). Evlilik İçinde Aldatılan Bireylerin Affetmelerini Yordamada Bağlanma Stilleri ve Psikolojik Sağlamlığın Rolü. Yüksek Lisans Tezi. Bahçeşehir Üniversitesi Sağlık Bilimleri Enstitüsü, İstanbul.

Güzel, İ. (2016). Yakın İlişkilerde Aldatma ve Affetme Eğiliminin Şema Terapi Modeli Çerçevesinde İncelenmesi. Yüksek Lisans Tezi. Bahçeşehir Üniversitesi Sağlık Bilimleri Enstitüsü, İstanbul.

Karasar, N. (2015). Bilimsel Araştırma Yöntemi (28. Baskı). Ankara: Nobel Akademik Yayıncılık.

Kaya, F. (2015). Üniversite Öğrencilerinin Affetme ve Mükemmeliyetçilik Düzeyleri Arasındaki İlişki: Duygusal Zekanın Aracı Rolü. Yüksek Lisans Tezi. Atatürk üniversitesi Eğitim Bilimleri Enstitüsü, Erzurum.

Kızılöz Başsayın, A. (2018). Evli Bireylerde Mükemmeliyetçilik, Evlilik Doyumu ve Cinsel
Doyum Arasındaki İlişkinin İncelenmesi. Yüksek Lisans Tezi. Okan Üniversitesi Sosyal Bilimler Enstitüsü, İstanbul.

Kublay, D. (2013). Evlilik Uyumu: Değer Tercihleri ve Öznel Mutluluk Açısından İncelenmesi. Yüksek Lisans Tezi. Karadeniz Teknik Üniversitesi Eğitim Bilimleri Enstitüsü, Trabzon.

Nalbant, H. (2017). Evlilik Uyumunun Yordayıcılarından Ahlaki Olgunluk ve Değerler. Yüksek Lisans Tezi. Gazi Osman Paşa Üniversitesi Eğitim Bilimleri Enstitüsü, Tokat.

Seyfi, S. (2017). Evli Bireylerin Aldatma Eğilimleri ve Affetme Düzeylerinin Bağlanma Stillerine Göre Incelenmesi. Yüksek Lisans Tezi, Çukurova Üniversitesi Sosyal Bilimler Enstitüsü, Adana.

Sivri, F. Z. (2019). Yetişkinlerde; Affedicilik, Iyimserlik ve Öznel Zindelik Düzeyleri Arasındaki İlişkinin Çeşitli Değişkenlere Göre Incelenmesi. Yüksek Lisans Tezi, Necmettin Erbakan Üniversitesi Eğitim Bilimleri Enstitüsü, Konya.

Tarhan, N. (2010). Aile Okulu. Timaş Yayınları (12. Baskı): İstanbul.

Tayşi, E. (2007). İkili İlişkilerde Bağışlama: İlişki Kalitesi ve Yüklemelerin Rolü. Doktora Tezi, Ankara Üniversitesi Sosyal Bilimler Enstitüsü, Ankara.

Tutarel Kışlak, Ş. (1999). Evlilikte Uyum Ölçeğinin (EUÖ) güvenirlik ve geçerlik çalışması. $3 P$ Psikoloji, Psikiyatri ve Psikoloji Dergisi, 7 (1), 50-57.

Tutarel Kışlak, Ş. ve Çabukça, F. (2002). Empati ve demografik değişkenlerin evlilik uyumu ile ilişkisi. Aile ve Toplum Dergisi, 2, 40-46.

Yalçın, H. (2014). Evlilik uyumu ile sosyodemografik özellikler arasındaki ilişki. Eğitim ve Öğretim Araştırmaları Dergisi, 3 (1), 250- 261. 


\section{Extended Abstract}

We feel strongly the emotions such as love and hate strongly and at the same time we get satisfaction from and painful disappointed in family relations. Mostly all individuals are born in a family and establish a new family through marriage in adulthood. Therefore, the concept of marriage, which has an important place in human life, has been the subject of many research. With accepting the idea that happy marriages will constitute happy societies, the secret of happy marriages has always been ambiguous. Marriages in which spouses feel themselves happy, peaceful and safe can be considered as successful. The harmony and solidarity between the spouses can also be seen the basis of successful marriages. If there is a healthy relationship between the wife and the husband then the expectations of spouses from marriage are quite high.

A harmonious, balanced, peaceful and happy family environment is also important and necessary for the children who grow up in that family. Because these children, as a social expectation, will be able to establish happy and healthy families. However, contrary to happiness, there are also other dynamics that may cause hurting to the feelings. The concept of forgiveness is considered to be very important in marriages, since being hurt in close relationships may be more important. In this context, from the idea of the concept of marital offense-specific forgiveness plays an important role in the relationship of marriage, the relationship between individual's level of marital offense-specific forgiveness and marital adjustment is analyzed in this study.

In the scope of this study correlational survey model is used to investigate the relationships between marital adjustment and marital offense-specific forgiveness level of married individuals. As a quantitative research 210 married individuals consisting of 125 women and 85 men are constitute the sample of this study. Marital adjustment was measured by the Marital Adjustment Test (MAT) developed by Locke and Wallace (1959), and the Turkish translation was conducted by Kışlak (1999). Marital offense-specific forgiveness was measured with the Marital Offense-Specific Forgiveness Scale (MOFS) developed by Palegari, Regalia and Fincham (2000) and Turkish translation was conducted by Akın, Çolak ve Eroğlu (2012). After the application, the data were analyzed with SPSS 24 package program.

According to the results of the research, it is seen that while the agreement dimensions of MAT's for the participants do not differ according to gender, education level, age, number of individuals working in the family, sector of employment, income level, marriage type, number of children; there is a significant difference between the duration of marriage and the age difference with the spouse with agreement. On the other hand, while the relationship style dimension of MAT's for the participants do not differ according to gender, education level, age, number of individuals working in the family, income level, marriage type and age differ with the spouse; there is a significant difference between the age, sector of employment, duration of marriage and number of children with relationship style.

The MOFS's resentment-avoidance dimension of married individuals do not differ according to gender, education level, age, number of individuals working in the family, sector of employment, income level, duration of marriage, marriage type, age difference with spouse and number of children and also the MOFS's dimension of benevolence do not differ according to gender, education level, number of individuals working in the family, sector of employment, income level, duration of marriage, marriage type, age differ with spouse and number of children except of age. There is a significant difference between this dimension and age.

There is a high negative relationship between agreement dimension (MAT) and resentment-avoidance dimension (MOFS) while there is no relation between agreement (MAT) and benevolence (MOFS) dimension. For this result it could be said that as the agreement level increases in marriage the level of resentment avoidance is decreases. Besides, there is a medium negative relationship between relationship style dimension (MAT) and resentmentavoidance dimension (MOFS) while there is no relation between agreement (MAT) and benevolence (MOFS) dimension. Then it could be said that again as the relationship style level increases in marriage the level of resentment avoidance is decreases. While the agreement level of MAT for married individuals differed significantly according to the duration of marriage and age difference with the spouse, the relationship style dimension of MAT shows a significant difference according to age, sector of employment, duration of marriage and number of children. In addition, it is found that benevolence dimension (MOFS) and age differ significantly.

As a brief discussion and conclusion according to the results of the research, it is found that marital offense-specific forgiveness differed significantly just by age. It is understood from here that the participants continued their marriages without forgiving. In this context, it may be suggested to the field experts to study the mediating role of perceived damage severity between the relationship of benevolence dimension (MOFS) and MAT. In addition, new researches with different working groups and/or different variables can make a great contribution in order to see consistency between results and guide to the researchers.

Lastly, as for application; it is seen that pre-marriage couples generally have expectations about marriage but mostly these expectations and experiences do not match to each other. For that reason, individuals may be disappointed in the first years of their marriages. As a preventive study, couples can be referred to marriage therapy before marriage. Also, they may be directed to the constancy service for individuals' expectations from marriage, the responsibilities of the marriage relationship and the specific structure of the relationship. Likewise, family counseling services can be widespread for married couples to support them when they need it. 